This work is licensed under a Creative Commons Attribution 4.0 International License.

Ovaj rad dostupan je za upotrebu pod licencom Creative Commons Imenovanje 4.0 međunarodna.

UDK 821.111.09 Stoppard, T.-2

Sayyed Rahim MOOSAVINIA

Shahid Chamran University of Ahvaz, Iran

moosavinia@scu.ac.ir

Fatameh RAEISI

Shahid Chamran University of Ahvaz, Iran

fatemehraeisi375@gmail.com
Prethodno priopćenje

Preliminary Communication

Primljeno 18. srpnja 2020.

Received: 18 July 2020

Prihvaćeno 7. rujna 2020.

Accepted: 7 September 2020

\title{
“STARK RAVING SANE”: A DECONSTRUCTIONIST READING OF TOM STOPPARD'S ROSENCRANTZ AND GUILDENSTERN ARE DEAD
}

\begin{abstract}
The focus of this study is the theme of Hamlet's madness in Tom Stoppard's Rosencrantz and Guildenstern Are Dead, which as a play based on Shakespeare's Hamlet, provides a critique on this theme through the perspective of Ros and Guil, who, by means of a reversal of minor and major characters, have become the center of the spotlight in Stoppard's play. The concept of madness in general is complicated, including many different aspects, among which the historical aspect is the most significant, as the definition of madness has evolved through different historical eras. By placing Stoppard's Rosencrantz and Guildenstern Are Dead in a historical context, this essay aims to demonstrate that as a play written in the latter half of the twentieth century, Ros and Guil's critique of Hamlet's madness, with all the intricacies of its language, collapses the binary opposition of sanity and insanity in a twentieth century poststructuralist manner, and leads to no clear-cut answer to the question of Hamlet's madness. However, as a play whose events unfold in the context of Hamlet, a Renaissance play, it carries some of the social and political aspects of Shakespeare's
\end{abstract}


play, as Ros and Guil's evaluation of Hamlet's condition is heavily under Claudius's politically infused influence.

Keywords: madness, post-structuralism, deconstruction, Rosencrantz and Guildenstern Are Dead, Tom Stoppard.

\section{Introduction}

Set in the heart of Shakespeare's Hamlet, Tom Stoppard's acclaimed play Rosencrantz and Guildenstern Are Dead (first performed in 1966) provides a critique of the theme of Hamlet's madness, through the eyes of two minor characters from Hamlet: Rosencrantz and Guildenstern. This critique is a part of the broader critical body, which is the play itself, whose "value as theatre of criticism" (Berlin 269) has been discussed by other critics. Although this critical function might not have been the author's initial intention and "simply one of the by-products" (Jenkins 38), the two courtiers "speculating philosophically upon the 'reality' of a dramatic situation - the plot of Hamlet - which they cannot understand [,] . . o obliges Stoppard to adopt a critical view of the way in which his 'heroes' are handled by Shakespeare" (Brassell 37). Stoppard's "heroes"1 are Ros and Guil, Hamlet's childhood friends, who by means of reversing the major and minor character roles, have become the figures under the spotlight instead of the prince. They are sent to Hamlet with his uncle Claudius's instructions to find out the cause of his "transformation." This reversal of the roles provides us with a way of looking at various themes of Shakespeare's play through Ros and Guil's perspective, including Hamlet's madness, which is crucial to their mission and to their criticism. While Shakespeare treats these minor characters with little sympathy, Stoppard depicts them as the troubled, confused figures who are trying to make sense of the world around them - the context of Hamlet-and of Hamlet's mind, creating comical situations.

Here we refer to Ros and Guil as heroes with some caution. Although Brassell calls them "heroes" throughout his assessment of Stoppard's play, he also suggests that they are not traditional heroes as "the complex and lavish attention that 'heroes' traditionally receive" (39) is denied to them by the author. In other words, they are the focus of the play, but still not the main protagonists. Brassell believes that Stoppard's "objective is to explore the undeveloped nature of the perpetual minion, the man constantly relegated to the furthest recesses of the stage, without the faintest understanding of the action unfolding around him" (39). 
In order to see how the theme of Hamlet's madness has been treated in Stoppard's play and from the perspective of his Ros and Guil, we should bear in mind that madness, as shall be seen later in this paper, is a complicated concept with many different aspects, including historical, social, political, medical, literary and philosophical. Christopher Innes states that Stoppard's drama, in comparison to his contemporaries, is more focused on "philosophical issues rather than social problems" (393). Considering the fact that Rosencrantz and Guildenstern Are Dead contains a text rich with wordplay that deals with philosophical issues, the philosophical aspect of madness that concerns language within this play is significant. This point, however, does not dismiss the social aspect of madness-which is inevitably bound by history-from the play; Rosencrantz and Guildenstern Are Dead is a twentieth-century drama based on Shakespeare's Hamlet, a seventeenth-century drama, and madness as a social concept has changed throughout history from the seventeenth to the twentieth century. This research places the critique of Hamlet's madness in Stoppard's play within a historical context, to demonstrate the twentieth century philosophical collapse of the binary opposition of sanity and insanity in the intricacies of its language, and the political and social implications it carries from the seventeenth century play that is Hamlet.

\section{Madness and History}

Exploring the concept of madness in general is like going down the rabbit hole where at every corner lies a different definition based on a different perspective. Neurobiological, societal, and psychological models each provide different definitions (Hershkowitz 14-15). This concept can also be looked at in a literary sense as opposed to a clinical sense, as Branimir M. Rieger mentions in his introduction to Dionysus in Literature: Essays on Literary Madness. He emphasizes that in either sense opposing madness to sanity is an oversimplification, therefore the term madness remains "a fluid, ambiguous term encompassing many theories" (Rieger 1).

One crucial factor that adds to this ambiguity regarding the meaning of madness is history. Tracing madness in history, the work of Michel Foucault is especially influential. He "has attacked the problem of 'madness' by showing how the notion has historically been defined or described within specific social contexts" (Beaugrande 19). "In step with contemporary historicist discourse," Duncan Salkeld's study of madness in the age of Shakespeare "emphasizes the 
'constructedness' of madness,' which suggests that the meaning of madness as a political and social concept, "both in the historical moment and in that of contemporary discourse about that moment, must be constructed for a variety of different-political-reasons" (qtd. in Herold 94). Madness in this sense is a socially constructed concept that has never meant the same thing throughout different historical eras.

In an essay on madness in Shakespearean tragedy, Carol Thomas Neely outlines the historical evolution of the concept of madness. While in the Middle Ages madness was regarded "as possession, sin, punishment, and disease," affirming "the inseparability of the human and transcendent," in the early modern period it "began to be secularized, medicalized, [and] psychologized." The Renaissance gradually separated madness from such medieval considerations as supernatural and spiritual, attempting to establish the "secular human subject" (Neely 318-19). Following the eighteenth century's madness as symbolizing the animalistic side of humankind in need of being confined, and the nineteenth century's identification of madness with "immorality" that required "moral treatment" to be rectified, according to Neely, the boundaries that were constructed in the Renaissance between sane and insane started to collapse in the latter half of the twentieth century. This collapse takes place in both medical and philosophical domains; "the anti-psychiatry movement, and investigations into the chemical basis for mental disorders" mark the domain of medical practice, and in the domain of literary theory and philosophy, "reading madness functions subversively to blur boundaries" (Neely 317). Neely further explains that, in the latter domain,

[p] oststructuralist philosophers of radical skepticism like Derrida and Lacan, denying the possibility of a unified subject with continuous identity, of a coherent language that can ever say what it means, of "true" knowledge of the world, erase the boundaries between madness and sanity that were constructed in the Renaissance and strengthened and policed in the Enlightenment. (317)

Thus, the concept of madness in the later twentieth century can be looked at from the viewpoint of the philosophical and literary theories of the time; a poststructuralist attitude toward language as unreliable and the ultimate meaning as an unattainable myth would deconstruct the binary opposition of sanity and insanity, a binary that has its roots in the Renaissance. 


\section{Hamlet and Madness}

The secularization of madness in the Renaissance can be seen reflected in Shakespeare's drama, as discussed by Allen Thiher. The hermeneutics of Shakespeare, the demand in plays like Hamlet and King Lear for madness to be interpreted, according to Thiher, is a historical issue. He points out "that at the beginning of the seventeenth century, in spite of the sclerosis of medicine, it became possible to view madness as something other than an accident produced by humors, or diabolical possession, or animal lust, or the position of the stars" (Thiher 85). He concludes that "[m]adness in Hamlet and King Lear is a position in a context, a relation that must be interpretively explored, and one that can be positively evaluated (Thiher 85). The Renaissance definition of madness, therefore, is crucial to Shakespeare's depiction of Hamlet's madness, which necessitates its interpretation. This ultimately leads to what another critic refers to as "the plurality of Hamlet" (Cohen 102), its capacity to be interpreted in various ways.

This demand for interpretation has been met with various responses and the evaluations of Hamlet's condition abound, especially in two levels of feigned and actual insanity. A. C. Bradley draws a line between Hamlet's actual mental state (which he calls melancholy) and his feigned madness. He mentions the "fear of the reality" (Bradley 101) as the reason for adoption of this feigned madness and goes on to explain that it could be due "to an instinct of self-preservation, a fore-feeling that the pretense would enable him to give some utterance to the load that pressed on his heart and brain, and a fear that he would be unable altogether to repress such utterance" (Bradley 101). Bradley's interpretation of Hamlet's situation is melancholy, which is completely different from the madness he feigns (101). According to Oscar Wilde, the prince "has no conception of what to do and his folly is to feign folly ... to Hamlet madness is a mere mask for hiding of weaknesses" (qtd. in Smith 56). J. Dover Wilson similarly "argues, [that Hamlet's condition is] 'a mask of madness' to conceal a nervous breakdown" (qtd. in Smith 56). Therefore, at one level Hamlet's madness can be divided into real and feigned, and each of these categories contain layers of meaning that can be explored.

However, this division of Hamlet's condition into real and pretended madness does not hold for long, as the two sides blend into each other not only in Hamlet, but also in the ideas of critics. Hamlet definitely cannot be said to be 
in control of his feigned madness at all times in Shakespeare's play; at times something else slips through this "mask of madness," his real condition. As mentioned above, Bradley calls this real condition "melancholy"; he points to the possibility of the development of this condition into actual insanity and asserts, "[ $t]$ hat Hamlet was not far from insanity is very probable" (101). Similarly, T. S. Eliot states that Hamlet's condition is "less than madness but more than feigned" (qtd. in Smith 56). These remarks point to an integrated continuum with no clear border between real and fake madness. The problem of Hamlet's madness appears to be a bulk of mystery in which real and fake are intertwined, this being just one aspect of the whole question.

This mysterious bulk can be interpreted in a social light, to define Hamlet's madness according to the norms of his society. This kind of interpretation points to what Rieger mentions as one of the manifestations of madness in literature: "anomie, or sociological madness" (8). Characters like Hamlet, who are strangled with anomie, are "estranged from society's 'sane,' 'normal' or 'rational' behaviors" (Rieger 8). Anomie can paralyze or empower these characters; aside from those who are paralyzed by it - Kafka’s Samsa or Dostoevsky's Underground Man -anomie can help the characters "take more active steps as rebels or non-conformists to oppose society's constraints" (Rieger 8). Thinking of Hamlet's madness as a device that he uses to oppose the constraints of his society brings about another layer of interpretation, which leads us down a political path closely connected to Claudius, Hamlet's nemesis, who is a great enforcer of the said constraints.

This political path is explored by Gregory Shafer, who argues that madness in Hamlet is a political term observable in the political opposition of Hamlet and Claudius. Each of the two opposing sides use this term to their own advantage; Claudius "to establish his power over Hamlet" and marginalize him, and Hamlet to undermine that power (Shafer 42-44). In this political struggle, it seems that Claudius is working toward making an anomic of Hamlet, who in turn proceeds to make use of this situation to retaliate. Anomie in Hamlet's case, can therefore be said to have political purposes.

\section{Stoppard and Hamlet's Madness}

To conduct an analysis of Hamlet's madness in Stoppard's Rosencrantz and

Guildenstern Are Dead, we should start from the very beginning, when Ros and 
Guil are given a mission by King Claudius. They are briefed about "Hamlet's transformation," and are assigned to "draw him on to pleasures" and "glean what afflicts him" (Stoppard 40). Ros sums it up in twentieth century words as "cheer him up - find out what's the matter" (Stoppard 40), and from there they get on with this mission that turns into a critique of Hamlet's state of mind that what Guil describes as a game of "asking the right questions" (Stoppard 40). This process can roughly be divided into three phases: before they meet the prince, immediately after the meeting, and in the presence of the Player.

The first phase starts when Ros and Guil spot Hamlet from afar and, based on that fleeting observation and more on Claudius's assertions, affirm his transformation. In fact, they just repeat what they were told. To glean what afflicts the prince, they start a game of question and answer, at the beginning of which they digress a bit due to Ros's confusion. The outcome of this game of language is a summary of Hamlet's situation by Ros: "[Y] our father, whom you love, dies, you are his heir, you come back to find that hardly was the corpse cold before his young brother popped on to his throne and into his sheets, thereby offending both legal and natural practice. Now, why exactly are you behaving in this extraordinary manner?" (Stoppard 51). Putting it in this ironic way, Stoppard seems to criticize Ros and Guil's evaluation of the situation. They clearly give a plausible answer to the question but fail to logically connect the two. Just a few lines before, they had described Claudius's ascension to the throne instead of Hamlet as "unorthodox" and "usurpation," and his marriage to Hamlet's mother as "extraordinary," "indecent," "hasty" and "suspicious" (Stoppard 49-50). Although they have already stated the answer in their game, Guil's following line saying, "I can't imagine!" (Stoppard 51), adds to the ironic effect and affirms their indecisiveness in this phase.

After meeting with Hamlet in phase two, we might expect from the two courtiers a clearer evaluation of the prince's situation, but they seem to be even more confused and frustrated. According to their evaluation, the conversation with Hamlet has been a losing game of question and answer. Guil's final diagnosis as he puts it, is "thwarted ambition - a sense of grievance" (Stoppard 57), and Ros goes with "depressed" (Stoppard 57), summing up their defeat in the game against Hamlet with much frustration:

Six rhetorical and two repetition, leaving nineteen, of which we answered fifteen. And what did we get in return? He's depressed! . . Denmark's 
a prison and he'd rather live in a nutshell; some shadow-play about the nature of ambition, which never got down to cases, and finally one direct question which might have led somewhere, and led in fact to his illuminating claim to tell a hawk from a handsaw. (Stoppard 57)

That "one direct question" is included, from the original Hamlet, in Ros and Guil's conversation with Hamlet, which is significant due to the fact that most of that conversation takes place offstage in Stoppard's play:

HAMLET. . . But my uncle-father and aunt-mother are deceived.

GUIL. In what, my dear lord?

HAMLET. I am but mad north north-west; when the wind is southerly I know a hawk from a handsaw. (Stoppard 55)

This might be Hamlet's warning to his old friends, whose real reason for their visit he has figured out, that he might actually be mad sometimes but in fact he knows what is what. ${ }^{2}$ Ros and Guil, however, seem to take it literally, which only leads to a fade-out of the discussion into a comical sequence of trying to "establish the direction of the wind" (Stoppard 59).

There is indeed someone who knows "which way the wind is blowing" (Stoppard 66) - the Player, in whose presence the third phase takes shape. Yet, what significance lies in the presence of the Player? In Stoppard's play, according to Richard Corballis, "[c] oherence is evidently dependent on the presence of some member of the Hamlet cast" (73). To illuminate this point, Corballis draws attention to an instance in the play when the two courtiers, "after a series of unsuccessful attempts, suddenly get their names right at the very moment when Hamlet crosses the stage. But as soon as he disappears the old confusion returns" (72-73). Throughout the play, Ros and Guil appear to be quite confused about their position in the plot of Hamlet, but this confusion seems to subside in the presence of the cast of Hamlet. Just like that, in the third phase, in the presence of the Player and through a conversation with him, Ros and Guil finally reach a conclusion about the prince's mental state.

Can Hamlet be trusted here? Thiher points out Hamlet's own uncertainty regarding his situation, suggesting the "possibility that his is the greatest madness, self-conscious, and self-denying, interpreting his own madness as feigned when he is mad" (84). This adds another layer to the critique of Hamlet's madness in Stoppard's play. 
After telling him about their confusions, the Player guides Ros and Guil through organizing their assumptions using questions and answers. He questions their answers to Hamlet's problem at every turn, through which the duo comes up with such words as "melancholy," "mad," "morose" and "moody" to describe the prince's situation. He keeps questioning their choice of words and the answers that are shrouded in uncertainty:

GUIL. He's - melancholy.

PLAYER. Melancholy?

ROS. Mad.

PLAYER. How is he mad?

ROS. Ah. (To GUIL.) How is he mad?

GUIL. More morose than mad, perhaps.

PLAYER. Melancholy.

GUIL. Moody.

ROS. He has moods.

PLAYER. Of moroseness?

GUIL. Madness. And yet. (Stoppard 67)

They then follow a train of thought that leads them to another way of putting it:

ROS. He talks to himself, which might be madness.

GUIL. If he didn't talk sense, which he does.

ROS. Which suggests the opposite.

PLAYER. Of what?

(Small pause.)

GUIL. I think I have it. A man talking sense to himself is no madder than a man talking nonsense not to himself.

ROS. Or just as mad.

GUIL. Or just as mad.

ROS. And he does both.

GUIL. So there you are.

ROS. Stark raving sane. (Stoppard 67-68)

This conclusion is by far the best answer Ros and Guil have achieved, and they seem to be satisfied with its logic. Yet, what does this even mean? On a 
literal level, they might have actually come up with a clear answer, a sane person raving (talking nonsense). Therefore, Hamlet is not mad but merely talks like one. However, this expression, "stark raving sane," is actually a modified idiom, instantly reminding us of the original form "stark raving mad." Thus, it contains both meanings, as if the two have packaged their confusion between madness and sanity into one expression.

The Player, however, answers Ros's line with a "Why?" and with that draws the discussion in another direction. He seems to suggest the question they should ask and find the answer to is-as Guil interprets for Ros- "Why is he mad?" (Stoppard 68). This question reminds us of another: Why has he transformed? This is basically Claudius's initial question. When they fail to answer the question, he leads them toward a conclusion; he tells them that Polonius thinks Hamlet is in love with Ophelia. Ros immediately concludes that the problem is one of "unrequited passion" (Stoppard 69). This conclusion was actually overshadowed in the previous act; when Ros and Guil receive the orders from Claudius, the original Hamlet text fades out with Polonius's lines as the cast of Hamlet exit the stage:

... And I do think or else this brain of mine

Hunts not the trail of policy so sure

As it hath used to do, that I have found

The very cause of Hamlet's lunacy.... (Stoppard 37)

Here, at the end of phase three, we once again come to the "very cause" that Polonius was talking about, this time through the Player's remark. With that, Stoppard's critique of Hamlet's madness through the eyes of his recycled characters Ros and Guil comes to an end, and we do not hear anything else on the matter from these two.

\section{Deconstruction of Madness}

A deconstructionist aspect can be traced in Stoppard's text regarding the concept of Hamlet's madness, whereas the border between sanity and insanity is blurred, and the binary can be said to collapse in the language of Ros and Guil, in a late twentieth century philosophical context. As we observed earlier, the latter half of the twentieth century saw the collapse of the border between sane and insane, in medical practice as well as literary and philosophical theory. 
Important in the latter dimension was the poststructuralist view of language as incoherent and unable to lead to an ultimate meaning. In a play rich with word play and linguistic games, which is more about language and dialogue than plot and action, as Guil puts it: words are "all we have to go on" (Stoppard 41). Yet, are they trustworthy enough to give a final answer to the question of Hamlet's madness or do they further obscure the matter? The instability of the language they use suggests that the latter is the case.

Language entraps and confuses Ros and Guil, creating funny moments for the audience and at the same time putting distance between them and clear judgment. In phase one, their game of question and answer goes wayward right at the beginning when Ros gets confused about how to play. They digress yet again after another failed game of question and answer-this time with Hamlet-in phase two; following Hamlet's hawk and handsaw remark, their conversation leads to an existential debate on their position in the surrounding world, off and away from the question of Hamlet's madness. Then we see in phase three how the Player guides them toward an answer, through a conversation that seems like another game of question and answer. This back-and-forth exchange between Ros and Guil and the Player seems to demonstrate the inherent uncertainty of language, its capacity of being questioned and getting twisted. Their reasoning keeps getting twisted and nullified at every step and reaches a vague conclusion: "stark raving sane," the key point of this argument, a phrase that points toward the binary of sanity and insanity in Hamlet's case at the same time that it blurs the boundary and collapses it. Finally, as we have seen, no clear answer to the question of Hamlet's madness emerges from Ros and Guil's struggles with language.

Although we might have not achieved a final answer, since the play's context is Shakespeare's Hamlet, through Ros and Guil's critique of Hamlet's madness an undeniably political side can be traced. The two are at the king's service, and the king's political conflict with Hamlet and its effect on the whole situation of Hamlet's transformation is a major theme in Shakespeare's play. As the events of Stoppard's play unfold in the context of Shakespeare's, this aspect of the original Hamlet remains, and can be seen reflected in Ros and Guil's evaluation of Hamlet's condition.

In phase one, when Ros and Guil see Hamlet for the very first time, with no strong logic and merely based on Claudius's briefing, they confirm Hamlet's 
"transformation." After they summarize Hamlet's situation and evaluate it, they fail to see the logic in their own conclusions, as if the king's judgment of Hamlet stands between them and logic. After all, they are told to find "something more than his father's death" (Stoppard 43). In phase two, when Guil relates Hamlet's situation to his ambitions, "thwarted" ones, there is a trace of the king's manipulation, adding a political shade to this interpretation. Later in this phase, Hamlet's lines from the original play of Hamlet are included to warn the two attendant lords, because he has discovered them to be the king's-his rival'smercenaries. The last phase brings them to where the first phase started, Polonius's interpretation, which the two apparently accept as the final verdict. This too has political undertones; if Hamlet's madness was due to his unrequited love for Ophelia, things would be much simpler for Claudius, who feels his political position is threatened by Hamlet. Claudius's attempt to use the discourse of madness to his advantage, to "[establish] the binary oppositions for insanity" (Shafer 44), to marginalize the prince and manipulate others' assumption of him (creating a mist of anomie around his nephew) and Hamlet's reaction to that, appear influential in Ros and Guil's point of view.

\section{Conclusion}

What makes Rosencrantz and Guildenstern Are Dead much more than just a twentieth century remake of Hamlet is its ingenious structure built upon a deconstruction of Shakespeare's play by reversing major and minor character roles, which has inevitably led to a reversal of the main themes as well. This study has been an attempt to unfold this reversal, and focus on the theme of Hamlet's madness, which is a minor theme in this play. ${ }^{3}$ We explored Hamlet's madness from Ros and Guil's perspective, to find a multi-layered critique of the prince's mental condition created by the use of language in the play. Ros and Guil's critique of Hamlet's madness, as a part of a twentieth century play, aligns with the later twentieth century philosophical theories about madness that blur the line between sanity and insanity. This collapse of the binary is reflected in

Although a minor theme in this play, Hamlet's madness serves the play's major themes such as fate and death. The mission to find out the reason for the prince's affliction gives Ros and Guil a purpose, a reason for their existence in the world around them at first, and gradually starts confusing them and making them question their own situation and position in the context of Hamlet. An instance where this can be tracked is the discussion about the direction of the wind-their own direction in this chaos-which had originally started from deciphering Hamlet's enigmatic remarks to find out something about his mental condition. 
the unstable language the two courtiers struggle with throughout their critique and culminates in Ros's made-up expression "stark raving sane." In other words, they cannot reach a final verdict and decide whether Hamlet was sane or insane, which shows that the matter cannot be simplified in terms of a binary opposition.

While achieving a clear-cut answer does not seem probable, we can explore different aspects to the problem of Hamlet's madness in Stoppard's play, which, although not complete, can give us an insight toward a fuller understanding of the play and this theme. The perspective of historical context also plays an important role in our understanding of the concept of madness in general as the theme of Hamlet's madness in Shakespeare's play is influenced by the context of its time. Various aspects and functions of this theme have made it subject to many interpretations, implying the plurality of Hamlet regarding the title character's mental condition. One such interpretation concerns the political struggle of Hamlet and Claudius, and as Stoppard's play moves along the context of Shakespeare's Hamlet, some political undertones can be traced in Ros and Guil's critique, which is very much under the influence of Claudius's discourse of madness.

\section{Works Cited}

Beaugrande, Robert de. "Literary Theories and the Concept of Madness." Dionysus in Literature: Essays on Literary Madness, edited by Branimir M. Rieger, Bowling Green State U Popular P, 1994, pp. 17-31.

Berlin, Normand. "Rosencrantz and Guildenstern Are Dead: Theater of Criticism." Modern Drama, vol. 16, no. 3-4, 1973, pp. 269-77.

Bradley, A. C. Shakespearean Tragedy: Lectures on Hamlet, Othello, King Lear Macbeth. 3rd ed., Macmillan Education, 1992.

Brassell, Tim. Tom Stoppard: An Assessment. Palgrave Macmillan, 1985.

Cohen, Michael. "Hamlet: Madness and the Eye of the Reader." Dionysus in Literature: Essays on Literary Madness, edited by Branimir M. Rieger, Bowling Green State U Popular P, 1994, pp. 101-12.

Corballis, Richard. "Extending the Audience: The Structure of Rosencrantz \& Guildenstern Are Dead." ARIEL: A Review of International English Literature, vol. 11, no. 2, 1980, pp. 65-79.

Herold, Niels. "Madness and Drama in the Age of Shakespeare. A Review Article." Comparative Studies in Society and History, vol. 37, no. 1, 1995, pp. 94-99.

Hershkowitz, Debra. The Madness of Epic: Reading Insanity from Homer to Statius. Clarendon Press, 1998. 
Innes, Christopher. Modern British Drama: The Twentieth Century. Cambridge UP, 2002.

Jenkins, Anthony. The Theatre of Tom Stoppard. Cambridge UP, 1989.

Neely, Carol T. “'Documents in Madness': Reading Madness and Gender in Shakespeare's Tragedies and Early Modern Culture." Shakespeare Quarterly, vol. 42, no. 3, 1991, pp. 315-38.

Rieger, Branimir M. Introduction. Dionysus in Literature: Essays on Literary Madness, edited by Branimir M. Rieger, Bowling Green State U Popular P, 1994, pp. 1-15.

Shafer, Gregory. "Madness and Difference: Politicizing Insanity in Classical Literary Works." Language Arts Journal of Michigan, vol. 30, no. 1, 2014, pp. 42-47.

Smith, Susan H. "Ironic Distance and the Theatre of Feigned Madness." Theatre Journal, vol. 39, no. 1, 1987, pp. 51-64.

Stoppard, Tom. Rosencrantz and Guildenstern Are Dead. Grove Press, 2007.

Thiher, Allen. Revels in Madness: Insanity in Medicine and Literature. U of Michigan P, 2002. 


\title{
„ŠTO RADI ZDRAVOUMAN“: DEKONSTRUKCIJSKO ČITANJE DRAME ROSENCRANTZ AND GUILDENSTERN ARE DEAD TOMA STOPPARDA
}

\author{
Sažetak
}

\section{Sayyed Rahim MOOSAVINIA}

Sveučilište Shahid Chamran u Ahvazu, Iran

moosavinia@scu.ac.ir

Fatameh RAEISI

Sveučilište Shahid Chamran u Ahvazu, Iran fatemehraeisi375@gmail.com

Rad tematizira Hamletovo ludilo u drami Toma Stopparda Rosencrantz $i$ Guildenstern su mrtvi, utemeljenoj na Shakespeareovu Hamletu, te donosi kritiku kroz perspektivu naslovnih likova koji zahvaljujući Stoppardovoj inverziji sporednih i glavnih lica dospijevaju u prvi plan. Koncept ludila općenito je složen i uključuje mnogo različitih obilježja, posebice povijesna s obzirom na to da se definicija ludila mijenjala kroz različita povijesna razdoblja. Smještanjem Stoppardova Rosencrantza i Guildensterna u povijesni kontekst, rad pokazuje kako kao drama napisana u drugoj polovici 20. stoljeća njihova kritika Hamletova ludila sa svim zamršenostima svojega jezika podriva binarnu opoziciju zdravog razuma i ludosti kroz poststrukturalizam 20. stoljeća i ne daje jasan odgovor na pitanje Hamletove ludosti. Međutim, kao drama čija je radnja protkana kontekstom renesansne drame Hamleta, ona odražava određena društvena i politička obilježja toga Shakespeareova djela, budući da na Rosovu i Guilovu procjenu Hamletova stanja velik politički utjecaj ima Klaudije.

Ključne riječi: ludilo, poststrukturalizam, dekonstrukcija, Rosencrantz i Guildenstern su mrtvi, Tom Stoppard 